\section{A SURVEY OF ORIENTAL GRASSES}

The Grasses of Burma, Ceylon, India and Pakistan (excluding Bambuseae)

By Dr. N. L. Bor. (International Series of Monographs on Pure and Applied Biology. Division : Botany, Vol. 1.) Pp. xviii + 767. (London and New York: Pergamon Press, 1960.) 160s. net.

TOTHING gives greater pleasure than to welcome 1 a comprehensive work based on dedicated study by a recognized authority. The author of this book began his work on the Gramineae more than thirty years ago, and it deals with the species, both wild and introduced, of 243 genera of this important family which occur in the sub-continent of India. Presented mainly as a practical handbook, it surpasses the author's modest claims.

The general part of the text gives an excellent account of the morphology of the grass plant (pp. 1-22), deals with dispersal methods, uses of grasses and enumerates certain obnoxious ones. Unfortunately, not all these unusual observations are indexed. The systematic part of the text (pp. 61-681) presents the genera and species grouped in three tribes of Panicoideae and thirty-six of Pooideae. Critics of the alphabetical sequence should read carefully the reasons given on p. 77, and bear in mind the problems implied, as well as exemplified, in the concise, but cogent, section on taxonomy and phylogeny (pp. 61-76). Taxonomists will wish to know the precise date of publication; this was December 14, 1960. The eighty line-blocks, though uneven in style and quality, are of particular interest in showing a comparison of the work of the ten artists. (Not mentioned in the book, they are: Mr. G. Atkinson, Dr. Bor (Figs. 3, 4 and 70), Miss L. Ripley, Miss S. Ross-Craig, Mr. J. Shaw, Miss M. Smith (Figs. 31 and 77), Miss E. M. Stones, Mrs. O. Tate, Mr. P. Taylor and Mr. W. E. Trevithick). The bibliography is good, including almost 600 items; the 89 works by Dr. Bor testify to his preparatory industry. The index lists about 4,800 entities, but omits all varieties. The author acknowledges his indebtedness to J. D. Snowden in the genus Sorghum, and Dr. A. Melderis has given assistance in the Triticeae.

The magnitude of Dr. Bor's achievement can be gauged from the number of taxonomic entitios involved : the 243 genera include 1,250 (士 5) species, but the index shows that he has also placed some 3,500 specific synonyms. Ninety-seven of the genera are monotypic in the area ; 60 per cent have less than three species (high proportions, even for Gramineae, perhaps because of introductions); thirty-two have more than ten. The author gives full synonymy for the genera, he has checked all references, examined almost all the type specimens (but does not indicate which) and gives caryological data. The taxonomy is commendably explicit, with full notes covering difficult cases ; but one regrets the author's caution, as so fow will reach a better position than he to decide some of the issues he leaves "to later research". Need he have deliberately placed the same nine spocies in both Erianthus and Saccharum? As to the nomenclature, the author's deep concern with the plants themselves seems to have made him impatient of some of the niceties of the International Code. The inclusion of the same new variety in both Andropogon polyptychus and Dichanthium polyptychus makes it invalid (vide Article 33), like the new combination similarly duplicated on pp. 151 and 212. The text is unmarred by typographical errors, but users may add Ischnochloa, Sorghastrum and Themeda to the list of Andropogoneae on p. 80 .

Dr. Bor has completed a study of noble proportions which will become relied on for Asiatic grasses as is Hitcheock's invaluable manual for the North American ; the keys make it more useful, the lack of descriptions being less of a handicap for grasses where keys so often use technical characters. Significant scientifically and superlatively well written, the book shows a beautiful balance of original and derived information; at every opening one observes the author's practical knowledge of the grasses of India and his familiarity with the academic sources. This fitting addition to the literature is especially welcome at the present stage in the development of agriculture in Asia. What a pity the high price will tend to restrict ownership of the book to institutions.

JOHN LEWrS

\section{VIRUSES IN DISEASES OF CHILDREN}

\section{Viral Infections of Infancy and Childhood}

A Symposium of the Section on Microbiology, The New York Academy of Medicine. Edited by Prof. Harry M. Rose. Pp. xi +244. (New York: HoeberHarper, 1960.) 8 dollars.

\footnotetext{
$T$
} HIS beautifully produced symposium provides a concise account of recently acquired knowledge and current concepts in its chosen field. The approach is epidemiological, with the accent on laboratory aspects.

The first two chapters summarize recent work on the infectivity of ribonucleic acids extracted from poliovirus (H. E. Alexander) and from virusinfected cells (J. S. Colter)-excellent accounts, though of questionable relevance to many readers of this book. About half the 232 pages of text are devoted to enteroviruses, opening with chapters on coxsackie infections (H. L. Hodes) and virus myocarditis (S. van Creveld). The latter chapter gives a particularly useful review and an account of the outbreak of Coxsackie myocarditis of the newborn in Amsterdam in 1955. This dangerous disease is a threat to infants in the nurseries of maternity units, and van Creveld suggests the possibility of active immunization of pregnant women or gamma-globulin prophylaxis for infants born during epidemics of 'summer grippe'. The general properties of $\mathrm{ECHO}$ viruses are described by J. L. Melnick, and A. B. Sabin presents a particularly well-arranged review of the role of $E C H O$ viruses in human disease. Fever, meningitis, and sometimes skin rash have been prominent features of various outbreaks, but associations with such other symptoms as diarrhcea and respiratory illness also appear to be significant. D. A. J. Tyrrell and his colleagues describe their investigations on the outbreak of meningitis and skin rash in England in 1956, caused by type $9 E C H O$ virus, which resembles a Coxsackie group $A$ virus in its virulence for suckling mice. Long-term observations of enterovirus infections among children in a Washington orphanage are summarized by $\mathrm{L}$. Rosen and associates. Dalldorf discusses the increasingly recog. 